\title{
THE TEMPORALIZATION OF LISTENING IN THE INTERSUBJECTIVE RELATION
}

\section{IRINA POLESHCHUK}

$\mathrm{PhD}$ in Social Sciences, University of Helsinki, post-doctoral researcher at the Faculty of Economics and Political Studies, 09240 Espoo, Finland.

E-mail: irina.poleshchuk@helsinki.fi

The paper explores the ethical significance of listening in intersubjective relations with another person. Rooted in Levinas's account of intersubjective temporality this research discusses listening as a vision of responsibility, as a welcome of the other and as a possibility to realize responsibility as being for the other. The main focus is to analyze listening as a disturbance of ethical subjectivity and as a traumatic experience, and to understanding how an expression of the face of the other requires an ethical response in the form of attentiveness and listening. Referring to Levinas's ethics I show that listening grows from the function of auto-affection and affection. First, I bring into discussion a description of prereflective subjectivity, which has not yet encounter the appeal of the other. I analyze subjectivity in its displacement and the sense of pain. Then I turn my attention to the work of affection in temporalizing consciousness and how it results into a temporal gap, dephasing, into a non-intentional consciousness and passivity. All these create an important context to locate the meaning of the ethical listening as a formation of the present. I will also give a special account of sensibility and corporeity, which arise from the notion of affection and non-intentional consciousness, and which, gradually, form driving principles of synchrony and diachrony. Thus, the main goal of this paper is to illuminate the principle why listening is seen as a specific mode of temopralization for subjectivity and of reasoning responsibility, and how listening is initiated by diachronical movement and how it is found at the basis of the face-to-face situation.

Key words: intersubjectivity, affection, dephasing, diachrony, the other, temporality, non-intentional consciousness, welcome.

\section{ТЕМПОРАЛИЗАЦИЯ СЛУШАНИЯ В ИНТЕРСУБЪЕКТИВНОМ ОТНОШЕНИИ}

\section{ИРИНА ПОЛЕЩУК}

Доктор философии, исследователь-постдокторант Университета Хельсинки (Финляндия), факультет экономических и политических исследований, 09240 Эспоо, Финляндия.

E-mail: irina.poleshchuk@helsinki.fi

(C) Irina Poleshchuk

HORIZON 4 (1) 2015 
Центральным сюжетом данной работы является идея слушания в интерсубъективных отношениях с другим. Обращаясь к теории интерсубъективной темпоральности, представленной в работах Левинаса, данная статья анализирует слушание как определенную модальность темпорализации ответственности, пассивности и как гостеприимство другого. Основной фокус описать слушание как образ особого рода беспокойства и лишения локуса, как травматического опыта, и понять, как опыт осознания обращения лица другого необходимым образом призывает к этическому ответу в формах самоаффективности и аффективности. Особое внимание уделяется описанию до-рефлективного опыта субъективности, спровоцированного аффектом: сдвиг, смещение, лишение места, потеря времени и боль. В статье исследуются основания слушания, обнаруженные в темпорализирующемся сознании, а именно, как они сформированы в феноменологии этики Левинаса: концептуальная роль аффекта, темпоральный разрыв и дефазирование, неинтенциональное сознание, диахрония и пассивность. Описывая роль аффекта, автор пытается проследить основания возможности ответственности в форме слушания другого, сформированной в моменте настоящего и обнаруженной в диахронической темпоральности. Таким образом, основная задача статьи - объяснить слушание через принцип диахронии и как способ возможной реализации этической тепморализации субъективности, обнаруженный в акте обращения другого и в основании ситуации лицом к лицу с другим.

Ключевые слова: интерсубъективность, аффект, дефазирование, другой, темпоральность, неинтенциональное сознание, гостеприимство.

\section{Introduction}

The ethical dimension of listening has been widely discussed in studies that accentuate the meaning of rights, freedom, justice, identity and otherness. The human response to the other in the form of listening is not just a nostalgic retreat into the ideality of ethics and moral norms needed to foster our contemporary community. To listen is to be ready to give an ethical response and to be responsible in the immediacy of the communicative event. I believe that the philosophical insight found in the works of Emmanuel Levinas enlighten us to the significance that the gesture of listening occupies in our intersubjective relations with another person. Even without addressing listening explicitly in any methodical way, Levinas still presents us with a vision of responsibility, and the welcome of the other, as contained in and by listening. This study brings together a discussion of listening as an ethical response, as well as a particular form of intersubjective temporalization in the phenomenological tradition, and presents an analysis of listening as a disturbance of ethical subjectivity and as a traumatic experience.

Before turning to the main argument of this paper I would like to give a short description of the phenomenological basis upon which the encounter with the other (and equally all phenomena including the other human being) rests for intentional consciousness. In very general terms, the main conceptual ground of phenomenology is intentionality understood as consciousness of. Within the intentional flow, the object of perception is given to consciousness, but at the same time consciousness is compelled to react to the givenness of the object and to comprehend it. Thus, intentionality implies that 
there are two sides consciousness's construction of the perceived object that happen simultaneously. On the one hand, consciousness apprehends the object by moving beyond the object's immediacy, i. e. beyond the immediate presentation. In this case, the object is given as a variety of characteristics, profiles and features that are not immediately grasped. In other words, the presentation is combined with appresentations ${ }^{1}$ of other possible profiles. On the other hand, the perceived object affects consciousness and provokes it to react. This enrooted affectivity draws upon the ability of consciousness to construct the appeared phenomenon in a complete way. This completed knowledge of the object implies a series of temporal phases - the past, the living present and the future to come - through which consciousness moves in order to make an experience hold together as a whole. ${ }^{2}$ In her extensive work on the phenomenology of intersubjective temporality, Lanei Rodemeyer notes that «temporalizing consciousness $\langle\ldots\rangle$ is able to go towards something else, beyond the immediate presentation, and $\langle\ldots\rangle$ is able to hold onto experience so that a presentation can be appreciated as presenting a single, whole object» (Rodemeyer, 2006, 4). It is important to see temporalizing consciousness as a source for any cognitive activity. However, since one of the main projects of phenomenology is to analyze the ethical encounter, it is also possible to unfold the various meanings contained within our relations with other subjects, through an examination of temporalizing consciousness. ${ }^{3}$ In this paper, affectivity, being a part of the process of temporalization, plays a significant role in determining not only our relation with objects and the way they appear for us, but is also considered to be the fundamental ground for our ethical intersubjective relation with otherness, that constantly recasts subjectivity.

I suggest that, along with affectivity, listening occupies a privileged place in the temporal intersubjective relation. In this paper my intention is to show how listening grows from the function of affection in temporalizing consciousness and how it acquires its ethical meaning for subjectivity in the face-to-face relation with the other. I strongly believe Levinas' view of the face-to-face relation is a key to understanding how an expression of the face of the other requires an ethical response in the form of attentiveness and listening.

${ }^{1}$ Here appresentation accompanies what is immediately given. While perceiving an object, only the moment of primal impression directly presents a particular aspect of it. However, to some extent we are also aware of other aspects of the presented object, namely appresentations. Appresentation might be seen as an experience of, or as «making present» of, what is not directly presented (Husserl, 1966, 114).

2 In «On the Phenomenology of the Consciousness of Internal Time» Husserl explains that the temporalization of consciousness happens as follows: retention fixes (holds) the experience of the justpassed, protention connects to the experience of what is about to come and primordial impression, Urimpression is the center, which serves as the core of an original presence and of the living moment of now (Husserl, 1991).

3 The argument that time consciousness is the foundation of intersubjective constitution is well elaborated by Rodemeyer in her book «Intersubjective Temporality. Its about Time» (Rodemeyer, 2006). 


\section{Face-to-face With the Other: Expression, Listening and Responsibility}

Contrary to Husserlian phenomenology, where consciousness is conceived as a starting point for all possible meanings, and where it is thought to already include the constituting activity of the other, Levinas conceives of the subject as arising toward and for the radical alterity of the other and as being affected by the appeal of the other. Moreover, the Levinasian phenomenology of ethics shows us that the self is not first for itself and then for the other, as if morality played a merely secondary role. Rather, the self first develops in being for the other human being. This logic becomes clear if we look at the intersubjective relation as ethical temporality where listening plays a significant role in constructing responsible subjectivity.

In one of his interviews Levinas states: «My work is to further the deformalization of time» (Levinas, 2001, 209). This project of deformalization of time aims, as Rudolf Bernet explains, at a transformation of the «egological transcendental subject into an ethical subject. One which is characterized not by its spontaneous, free power, but by a responsibility for the other, which comes from the other» (Bernet, 2002, 90). This transformation presupposes the following: the other human being is given to me in all his/her vulnerability and this vulnerability is revealed as having its origin outside the subject. This deformalization of time, which happens at the very moment I am involved in conversation with the other by listening and being attentive to him/her, that is by giving an ethical response, is at the center of my argument. In this situation the other precedes, exceeds and then reconstructs my own temporality.

To develop this argument I will first explain why the face manifests itself as expression and speech. Then I will show how the address, coming from the other person, demands subjectivity's response, which manifests in modes of listening and attentiveness. My next step will be to ground the work of listening and attentiveness in a phenomenological context by showing how affection and Urimpression do not belong only to the constitutive power of intentional consciousness but, on the contrary, arise from the expression of the face of the other and give birth to the various temporal modalities of subjectivity. All this will bring me to a discussion of the changes that subjectivity undergoes in the face-to-face relation. My focus will be on the traumatic experience provoked by response in the form of listening and by the diachronic temporalization of the intersubjective relation.

Before an immediate explication of the face-to-face relation and the conceptual role of expression I want to work through the challenging question: how do we differentiate between an experience of the other as an object or phenomena of our world, and an experience of the other as radical other? Why is the experience of the otherness of an object not as radical as that of the other as l'Autrui (as another human being)? In «Totality and Infinity» Levinas seizes upon the difference between experiencing the otherness of an object and the otherness of the Other: «..."the "intentionality" of transcendence is unique in its kind: the difference between objectivity and transcendence will serve 
as a general guideline for all the analysis of this work» (Levinas, 2004, 49). According to Glendinning, one of the authors who explicitly points out the difference between the experience of the alterity of an object and that of the other, Levinas sketches two intertwining ideas describing the experience of the otherness of an object and of the Other: the first kind of experience is appropriating power, the second kind is cognitive power (Glendinning, 2007, 158).

The first idea shows that the otherness of an object can be totally annulled:

The distance of transcendence is not equivalent to that which separates the mental act from its object in all our representations, since the distance at which the object stands does not exclude, and in reality implies, the possession of the object, that is, the suspension of its being (Levinas, 2004, 49).

Here Levinas accentuates the reduction of the alterity of the object, which constitutes the specificity of its being, as it occurs in cognition. Contrary to this, the experience of the other is an experience of transcendence and it cannot be annulled. As Levinas explains:

...the other remains infinitely transcendent, infinitely foreign; his face in which his epiphany is produced and which appeals to me breaks with the world that can be common to us, whose virtualities are inscribed in our nature and developed by our existence (Levinas, 2004, 194).

The intersubjective world is never abstract, it is a concrete relation with the other, where the address of the other person regulates and also inevitably disturbs the horizon of activities originating from subjectivity.

In «Totality and Infinity» Levinas talks about what he calls the naked face, a face that is not masked by the whole social apparatus of role and status. Rather, the naked face stands before us, completely exposed and vulnerable, infinitely other and absolutely singular. «The skin of the face is the most naked, most destitute ... there is an essential poverty in the face» (Levinas, 1985a, 86). The face is the face of a vulnerable You that is dependent on me. Yet it also faces me with «uprightness» — face-to-face. The face is «expression» — not just «something» that I look upon, that I hold in my gaze. It «faces» me, and this «toward me» is both a profound appeal going against indifference and a kind of accusation aiming to prohibit my violence toward you. The expression does not present any information about the other but, following Levinas, the main idea of an expression is that it presupposes a distinctive response from me: «...to approach the Other in conversation is to welcome his expression» (Levinas, 2004, 51). The fact that I recognize an expression is already a response. Moreover, recognition of an expression as well as awareness of the need of response implies a state of being attentive. 
The concept of the expression partly explains why the face of the other breaks into my world and calls out to me. The other calls forth my response, commands my attention, refuses to be ignored, makes a claim on my existence, tells me I am responsible. I will never be freed from the face of the other, so much so that Levinas says we are always held hostage to the other, that we are never released from the other's speaking to us and calling forth our response. «It is impossible to evade the appeal of the neighbor, to move away» (Levinas, 2006, 128). The other says, «I am here» - and appeals to us, commands us: «do not kill me».

Receiving the address of the other does not necessarily presuppose the immediate direct response usually required by the normativity of our action. At first it is a state of affectivity that subjectivity experiences: in being aware of the call of the other it is indeed forced to react. However, the reaction takes place as a gesture of listening. In this silent presence for the other, listening becomes an ethical attentiveness to the Other in saying «I am here». It is precisely here that I see the locus of an ethical subjectivity that engages itself in an intersubjective world. This just born level of communication relates to a different type of temporality, the stream of which is already initially interrupted and is diachronical in its essence. In this context another interesting issue to explore is how the temporality of subjectivity in listening and attentiveness is born and how existential modalities of the subject, as for instance being-for, temporalize in the face-to-face relation. These questions will be the main topic of discussion in the next part.

\section{Affection and Temporal Dephasing}

Having thus followed a terminological path in order to bring out the location of expression and listening, I now turn my attention to a number of cross-cutting concepts in Levinas's account of intersubjective temporality: temporal justification of the work of affection, affection as validity for impression, temporal gap and dephasing, non-intentional consciousness and passivity. The goal of this detailed explication is to create a framework illuminating the reason why listening is seen as a specific mode of temopralization for subjectivity and how it is found at the basis of the face-to-face situation.

While our perception is influenced by the object perceived - it is always situational and concrete. Experience of affection would imply circular intentionality: it is not merely a matter of mastering but is also mastered. It is not an intentionality of invading but also of being invaded. As Welton describes it: «In the case of perception I not only act but I am acted upon, I not only effect but I am caught up in a larger realm of affectivity» (Welton, 2000, 243-244). Subjectivity does not only intend objects but they at the same time draw me to them; objects are capturing our acts. This reflection helps to substantiate the appeal of the other as breaking up the intentional capacity of subjectivity. The crucial step to undertake in this discussion is to point out a double character of intentionality: 
it is affecting and it is affected by the address of the other. In an article dedicated to the role of affection in intentionality, Anne Montavont defines this affection as the passivity of the subject, which is affected. In other words, subjectivity is inevitably affected by the call of the other. But, this «being affected» motivates an active tendency towards the other (Montavont, 1994, 122). Affected consciousness, or sensible data is the first strange or alien content within the self. The power of the expression coming from the face of the other penetrates subjectivity and its affection excites the self as non-consciousness (Unbewußtsein) on the level of original hyletic (Urhyle) pre-consciousness. Consciousness is, first of all, aware of something foreign striking it. Affection appears in consciousness before being-for consciousness: I am affected before I know that I am affected. A similar interpretation of Husserl's notion of affection can be found in the article by Natalie Depraz: «Temporalité et affection dans les manuscripts Tardifs sur la temporalité (1929-1935) de Husserl». Depraz claims that the understanding of being affected comes, in a way, retrospectively, and the articulation of sensation, which makes me aware of affection and able to localize it in consciousness, becomes possible thanks to a preliminary passive synthesis (Depraz, 1994, 75).

In «La ruine de la representation» Levinas expresses the same idea by claiming: «every object appeals and creates consciousness by which its being shines and appears». ${ }^{4}$ This being-affected-with reveals itself to subjectivity before being opposed to the world in objective representation. I emphasize here the presence of a primary passivity that invades subjectivity. This state is significant for determining subjectivity as initially open towards otherness.

This double structure of affection inverts temporalizing consciousness. For Levinas, time is «not only the form that houses sensations and lures them into a becoming, it is the sensing of sensation, which is not a simple coincidence of sensing with the sensed, but an intentionality and consequently a minimal distance between the sensing and the sensed - temporal distance». Thus perceived, intentionality opens a fundamental difference between «intentionality that intends identifiable idealities» and «impressed consciousness» (Levinas, 1998 a, 144). Within this difference there lies what Levinas denotes as connection (lien) and shift (écart). Shift means «already not» but also «still here» and «presence for». The impression of a coming demand of the other is built of (on) affection, and following Levinas' line of reflection, there is a slight temporal shift that disturbs the living present of consciousness (subjectivity) while it is affected. The shift means (separate) consciousness targeting an impression yet without being an awareness of the impression. The idea of shift makes it possible for Levinas to accentuate the significance of a past moment that belongs to primary experience.

\footnotetext{
${ }^{4}$ «...tout object appelle et comme suscite la conscience par laquelle son être resplondit et, par là meme, apparait» (my translation) (Levias, 1974, 134).
} 
«The already past», the «just passed» are the very divergence of a proto-impression $<\ldots>$ the divergence of the Urimpression is the event, in itself primary, of the divergence of dephasing, which is not ascertained in relation to another time but in relation to another proto-impression that is itself «in on it» (Levinas, $1998 \mathrm{a}, 142$ ).

Temporalizing consciousness is dephasing from its living present; it is unable to hold the unity of constructed experience at the moment of now. The affection tears the temporal flow before consciousness is aware of its own source of time. Thus, the gap present in intentionality constitutes a diachronic relation where the source of time belongs to the otherness affecting and penetrating the synchronized time line of consciousness. (Levinas, 1998b, 159-178)

Thus, I argue that Levinas imparts a new dimension to the phenomenology of time by articulating the crucial aspect of alterity through the notion of experience: «proto-impression is wholly receptivity of an "other" penetrating the "same"». ${ }^{5}$ The significant accomplishment in his discussion of time is his notion that there is a constant aspect of the «no-longer» intruding upon consciousness. Levinas provocatively adds that «consciousness of time is not a reflection upon time, but temporalization itself; the after-the-fact of realization is the after of time itself» (Levinas, 1998b, 143). The time of the source of experience, not included in the time of the living present (transcendental consciousness), has always been passed by the moment whereby the experience, as a content given to consciousness, is retentionally modified. For Levinas, consciousness is not the now moment, but a moment in the past, always late in respect to itself: the primary time of the source of experience always remains in the past and does not coincide with the moment of the living present.

The primary source of experience here is the other addressing subjectivity. Evidently Levinas wants to legitimate structures, which model subjectivity as going «beyond itself» and as stripped from outside. This going «beyond itself» signifies a concretion of intentionality, which allows transcendence to appear not as a relation of correlation, but as a relation of the subject to a «fundamental disorder» (Levinas, 1985a, 89). To be «beyond itself» means beyond what might be rendered as present.

In receiving the expression of the face as coming from outside of the constituted present subjectivity is rendered as questioned, disturbed and passive and not able to expand its cognitive activity. These new modalities are foundational for enrooting our ethical listening for the other, and allows us to preserve the very alterity and vulnerability of the other: «The consciousness is affected, then, before forming an image of what is coming to it, affected in spite of itself. In these traits we recognize a persecution; being called into questioning, responsibility over and beyond the logos of response» (Levinas, 2006, 102). Here, the feeling of self gets a totally different interpretation — it is

5 The use of the term «Proto-impression» is equal here to «primal impression» or «Urimpression» (Levinas, 1998a, 143). 
associated with an impressed consciousness structured from the primary experience of being affected. Evidently, in order to substantiate the ethical relation, Levinas intends to reveal a subject that cannot be interpreted only in terms of consciousness. I will further elaborate on this statement in order to emphasize a concept of non-intentional consciousness and to locate listening and attentiveness within the non-intentional structure of an impressed consciousness.

In Levinas's ethical scenario, the other is presented as not falling under my power and, at the same time, he «escapes my grasp by an essential dimension even if I have him in my disposal» (Levinas, 2004, 39). The fact that the other befalls the ego demonstrates that the other is anterior to the subject. I have to strengthen here the argument that the other precedes the intentional act and that explains why consciousness is not directed towards anything, i.e., not aimed at anything. Levinas defines it as non-intentional consciousness: «The non-intentional is passive from the start, the accusative is its first case, so to speak $\langle\ldots>$ in the passivity of the non-intentional... the very justice of being posited in being is put in question; being is affirmed with intentional thought, knowledge and the grasping of the now» (Levinas, 2000, 22). To put it otherwise, there is indirect and peripheral awareness of being inhabited and penetrated by the appeal of the other. ${ }^{6}$ Subjectivity is called to respond before conceptualizing itself fully as a subject.

Non-intentional consciousness is the consciousness of passivity because it is late in respect to itself and the Other. Long before it could have said «I», it has been defined by the call of the other that has to be listened to (Levinas, 2006, 101). It is «innocent yet already accused» — of its right to be here and now. Because it has neither place, nor name; it is a state of presence, not in the moment of the present, but always in the past. It lacks the special daring inherent to intentional consciousness - the daring to establish itself in its being (Levinas, 1998b, 130). At the same time it is afraid of the very fact of this presence. Such consciousness has no «homeland» or «dwelling», it dares not enter, perform, or act (Levinas, 1998b, 132). Levinas conveys non-intentional consciousness not as being-in-the-world but as being constantly questioned. Likewise, the experience of the other is always in the past, it is always already gone the moment I am ready to respond, that is why my consciousness is «always becoming old and searching for lost time» (Levinas, 1998b, 166). The only gesture, which is left for subjectivity is to gain the lost time through responsibility - to listen in attentiveness, which is to give a response to the face of the other fading away into the past. Thus, following Levinas's exegesis I ultimately reinforce here the view that listening predates «becoming a subject».

Thus, this key description of diachronic time is not only found at the heart of Levinas's texts but actually predetermines the entire vision of the ethical encounter. The temporalization of subjecitivty is expanded by the expression coming from the face

\footnotetext{
6 A detailed study of this aspect of temporality and non-intentional consciousness is presented in Roger Duncan's article «Emmanuel Levinas: Non-intentional Consciousness and the Status of Representational Thinking» (Duncan, 2006, 271-281).
} 
of the other, and furthermore by being forced to give an answer, subjectivity acquires new existential variations in listening and being attentive. In the next chapter I will present a detailed explanation of the event of listening to the other and its traumatic character.

\section{Listening as a Trauma}

The complex thematic of listening in the intersubjective situation led us first to the temporalization of subjectivity, which enacts an opening up towards newly born temporal existential modalities. Now I look to analyze an event of belatedness and of being towards the future that are inherent components of the temporality of the intersubjective relation. In doing so, we are faced with a complex range of questions: How does our analysis of listening lead us to a new notion of the self? How is attentiveness possible within a temporal gap? Why does listening necessarily bear an ethical meaning? And, finally, why does listening involve a traumatic experience for subjectivity?

In being affected the flow of consciousness intends something other than itself; it transcends itself. At this point in my interpretation of the face-to-face relation I am emphasizing the primal impression as diachroninal and as built up on the affection of something wholly other that affects consciousness. As I tried to show, the fact of my being late conditions my passivity, and it is only in the passivity of non-intentional consciousness that any formulation or metaphysical question about «a place asserted», is put into doubt. In the relationship with the other, I from the very beginning discover myself disturbed by the other:

Diachrony is the refusal of conjunction, the non-totalizable, and in this sense, infinite. But in the responsibility for the other, for another freedom, the negativity of this anarchy, this refusal of the present, of appearing, of the immemorial, commands me and ordains me to the other, to the first one on the scene, and makes me approach him, makes me his neighbor (Levinas, 2006, 11).

Levinas wants to turn attention to a global non-intentional awareness that must first be distinguished from a reflective awareness of the self. ${ }^{7}$ I describe this non-intentional awareness as an attentiveness in which subjectivity finds itself renewed. However, it has a different nature. It is not an active state of being directed towards something but it is, in a way, an inverted receptivity because of being paralyzed by the appeal of the other while still desiring to give an ethical response.

7 See Duncan, Roger B. «Living Levinas: Non-intetnional Consciousness in Levinas and Karol Wojtyla» (Duncan, 2000, 189-204). 
Why do I speak here about a renewal of subjectivity? While being passive and non-intentional, subjectivity turns its attentiveness into openness, but as unconditioned welcoming. I am attentive to the other and I am listening to the other despite everything. Anterior address provides a new beginning for subjectivity - it creates an emerging notion of the self, provoked by affection and by further impending impressions. I would go even further to state that the experience of being attentive would be a newly created notion of the self, which bears an ethical sense. For Levinas self-awareness and the self's notion arise before any theoretical cognition in the non-intentionality of consciousness and in the passivity of consciousness, which, in this case, would be a modality of listening to. Here the conceptual work of affection and non-intentional consciousness reveals the importance of an intersubjective horizon: intersubjectivity is conceived as necessary in order to be aware of my own experience and to appresent the ethical meaning of my encounter with the other.

Here I must pause, however, to comment critically on this description of the new understanding of the self that arises in the gesture of listening to. This new self is rooted in the traumatic experience of the face-to-face relation. In Otherwise than Being or Beyond the Essence, Levinas describes affected subjectivity as displaced and deprived of itself: «The subject in saying approaches a neighbour in expressing itself, in being expelled, in the literal sense of the term, out of any locus, no longer dwelling, not stomping any ground» (Levinas, 2006, 49). For the subject, expressing itself means to be able to give an ethical response in the form of listening. However, through this awakening subjectivity loses its original position and original locus as a subject able to actively generate a cognitive gesture towards the other. Ethical listening turns out to be a traumatic experience for subjectivity: «The subject is not in itself, at home with itself, such that it would dissimilate itself in itself or dissimulate itself in its wounds and its exile, understood as acts of wounding or exiling itself» (Levinas, 2006, 49).

Why this «being expelled from» and «being not in itself» turn into traumatic experience? The dwelling subjectivity, grasped in its original locus, needs a careful description to shape a traumatism of listening. Interiorized in its locus, subjectivity is also aware of its own embodied state. Before subjectivity is capable of listening and hearing, it is a corporeity rooted in and nourished by the world and, as Levinas puts it, by the «living from». From the very start subjectivity delineates its existence as a sensibility of self-affection born by the relation with life itself. This sensual bathing in the world is its pre-reflective modus: the embodied subject, immerged into the life and in «living from», enjoys the world, which, in its turn, envelops and saturates subjectivity.

In «Material Phenomenology» Henry proposes to conceive a pre-reflective selfawareness as grounded in auto affection (Henry, 2008). In being self-affected through the variety of experiences of sensual life subjectivity manifests itself as sensibility. The auto affection unfolds a purely immanent feeling that subjectivity has of the concrete modes of its life: hunger, thirst and pain are revealed through their passive giveness. The intentional object constitution is absent in our experiences of hunger, pain, or dwelling. 
They are present as purely immanent experiences of life, as a self-manifestation or as a self-appearance. Levinas reads this immanent experience of life as enjoyment or as «living from» that constitutes vivacity of subjectivity primarily rooted in sensing itself. ${ }^{8}$

The conceptual background for reading auto-affection as localizing and punctuating a sensible embodied subjectivity can be also found in Henry's interpretation of autoaffection. Giving phenomenological analyses of the moving and sensing body Henry distinguishes two senses of auto-affection - the strong sense and the weak sense. In the first case the auto-affection admits the power of life itself and is actively involved in its, or, in other words, it is affected. Indeed the life itself affects subjectivity but also subjectivity is affecting the way it is experiencing the life. It is nothing else but an active self-affection. In the second case the weak auto-affection is formed as passivity, where the subject would be given to itself. Bathing and participating in life are both active and passive involvements. In other words the active auto-affection is reversed into passivity because the active state of the auto-affection is so radical and so powerful that it turns into the passive auto-affection. ${ }^{9}$

Both Levinas and Henry point out that in its integrity auto-affection discloses an interiority of the subject. Subjectivity is born only in the self-affecting state and being passive. This pre-reflective sensibility initiated in the auto-affection provides a path towards the description of the dwelling and enjoying, interiorized and localized subjectivity, which is a beginning for itself but is also an origin for any ethical gesture. Levinas writes:

What begins to be does not exist before having begun, and yet it is what does not exist that must through its beginning give birth to itself, come to itself, without coming from anywhere. Such is the paradoxical character of beginning which is constitutive of an instant. And this should be emphasized. A beginning does not start out of the instant that precedes the beginning; its point of departure is contained in its point of arrival, like a rebound movement (Levinas, 1978, 45).

\footnotetext{
8 In «Totality and Infinity» Levinas explains that «If the intentionality of "living from" which is properly Enjoyment is not constituted, this is therefore not because an elusive, inconceivable content, inconvertible into a meaning of thought, irreducible to the present and consequently unrepresentable, would compromise the universality of representation and transcendental methods; it is the very movement of constitution that is reversed» (Levinas, 2004, 129). Enjoyment of «living from» would seek to interrupt and question the transcendental method, which always tends to construct senses in representation. In enjoyment the constitution is reversed because in self-affectivity the sense of enjoyment is issued from and is constituted by what is enjoyed.

9 «L'Archi-intelligibilité appartient au movement interne de la Vie absolue qui s'engendre elle-même, n'étant rien d'autre que la façon selon laquelle ce processus d'auto-engendrement s'accomplit. La Vie s'engendre elle-même en venat d soi, dans la condition qui est la sienne et qui est celle de s'éprouver soi-même» (Henry, 2000, 29).
} 
This self-affecting subjectivity is not a pure conjunction of the self with itself, neither it is a retour to itself. Rather the self-affectivity differentiates a gap or a disparity in the self. The claim is that the function of auto-affection originates a birth of the ego as locus in the self. Therefore I read the conceptual work of auto-affection to priorize the existent over existence and to locate a sensible embodied subjectivity, which is, first of all, sensitive to activities of the world (Murawska, 2012, 376-377).

In dwelling and in «living from», but at the same time enjoying and bathing in the world the self-affected subjectivity is already determined as being here and as a body, which unfolds itself in the present. There is a particular temporal modality of subjectivity designated as being here of the body, which sketches its static character: in space the subject locates itself as a center and as a privileged locus, which is at the same time a localized body grasped in experiences of being at home (chez soi). Therefore the selfaffecting subject is a pure present, a temporal punctum and a center in terms of space and time. I go further to state that by holding its locus the self-affecting subject is tending to temporal synchronization that comforts its interiorized dwelling in the world. Here I emphasize that the auto affection also reveals the continuity of the self's inner-time, a projective-retentive temporalization of its being-in-the-world. The natural need of selfaffected subjectivity is to be able to return to the self that also means to come back to the core of the self and to preserve it as an identity. To exit its ecstatic existence the selfaffecting subjectivity needs a refuge, a possibility of withdrawal, or a retreat in the locus.

Therefore ethical listening questions a possibility of comforting retreat, being a punctum, synchronization and the present. Here the state of trauma is a specific mode of temporalization that occurs to subjectivity, at the core of which, one finds diachronic time. Here diachrony is read as a displacement provoked by the expression of the face of the other, anterior to the origin of the self:

(This) diachrony of time is not due to the length of the interval, which representation would not be able to take in. It is disjunction of identity where the same does not rejoin the same: there is non-synthesis, lassitude. The for-oneself of identity is now no longer for itself. The identity of the same in ego comes to it despite itself from outside, as an election or inspiration, in the form of the uniqueness of someone assigned» (Levinas, 2006, 52).

Certainly, here I take a further step in reading «despite itself from outside» as an existential passivity where, because of the inescapability of the call of the other, listening and attentiveness break down subjectivity by withdrawing it from identity and inverting its being. At this point the most important function of listening is as a new source of time brought together with attentiveness: the shift of time is also considered to be an end of my time and it is a beginning of the time of the other in me. The call of the other is, in fact, a work of primal impression built up on the affection that penetrates impressed 
subjectivity. Clearly, following this interpretation, subjectivity might be read as a newly born self in a gesture of listening to. This is a new identity within the ethical becoming of subjectivity.

Let me underscore here that the intersubjective relation discussed in Levinas' ethics is not an abstract structure but a concrete experience of the other facing anyone:

The face I welcome makes me pass from phenomenon to being in another sense: in discourse I expose myself to the questioning of the Other, and this urgency of response acuteness of the present - engenders me for responsibility; as responsible I am brought to my final reality (Levinas, 2004, 178).

What Levinas describes as a final reality is, in fact, a situation where to expose oneself to the questioning of the other uncovers a traumatizing experience which engages subjectivity in its act of listening and being attentive. The core of this trauma is temporal extension because listening is already temporalization itself, which, as Levinas puts it, is «prior to the verb without subject, or in the patience of the subject» (Levinas, 2006, 54). It is a passive exposure denuding the active essence of the subject itself since the address of the other as primal impression happens just before subjectivity is aware of it. This is a small temporal diphase detaching subjectivity from its living present. In other words, the face of the other is always in the past while the necessity to give an ethical response, i.e. to listen to the other, is in the present. One important difficulty appears here: the temporal character of the intersubjective relation reveals subjectivity as always late and as listening to the call from the past. To listen to the other is to be traumatized by the voice of the other always gone into the past. However, this trauma also has a productive force - subjectivity aspires to be ethically responsive and therefore awaits the expression, which is still to come. Here I suggest that attentiveness, based on nonintentional consciousness, also bears features of the future rooted within subjectivity itself. Listening as ethical response is not only listening to the address coming from the past but also, because of attentiveness and opened passivity, it becomes an origin of the future within subjectivity. Because to some extent we are always faced with others still to come, it gives us the possibility of realizing responsibility: the attentiveness of listening is an anticipation of the futurity of the address of the other. This is what I call an ethical becoming in listening for the other who is still to come. The ethical becoming as being for the other is unconditioned and is in spite of everything.

These are important moments of discovery that change the stance of subjectivity. Listening, attentiveness and passivity are not described as lifeless but are something that color my actions. Levinas actually refers to this in his analysis of the face-to-face situation: «Being attentive signifies a surplus of consciousness, and presupposes the call of the other. To be attentive is to recognize the mastery of the other, to receive his command, or, more exactly, to receive from him the command to command» (Levinas, 
2004, 178). Reading this passage, I equate attentiveness to the other with an ethical reception that welcomes the other. In locating the role of listening, I emphasize, first of all, the transformation of subjectivity: the discovery of a new understanding of the self, or perhaps it is better to call it self-ness, its dislocation and its own awareness of trauma is also a process of becoming for the other. I tried to propose an interpretation of listening that would help ground a phenomenological description of the ethical listener who is not only deconstructed but is also recreated in the awareness of listening and attentiveness.

The intersubjective horizon, grounded upon temporalization, itself originated from affection, and bears an analogy to the appeal of the other. The appresentation of the ethical meaning of the encounter with the other rests upon two overlapping streams: my subjective temporalizing consciousness and intersubjective temporalization. Within the framework of Levinas's philosophy my intention has been to reveal the foundations of our temporalizing subjectivity, not only as linked to, but also as originating from, the relation to the other. I added two new layers — listening and attentiveness — that reveal ethical subjectivity as faced with the expression coming from another human being.

Let me now summarize the main arguments elaborated in this paper. Only embodied, self-affecting and affected, sensing subjectivity and susceptible to the life is able to listen and to respond. Dwelling, possessing its locus, enjoying and living from its enjoyment, but also displaced, hungry, traumatized subjectivity is gradually metamorphosed. It passes from its core of synchronization to the dyachronization in listening to the other. The ethical origin, or the new self of subjectivity, is grasped in productive passivity because the primal impression affects subjectivity before it is aware of any cognitive gesture. However, the work of impression, affection, or the expression of the face, potentiates subjectivity for an ethical response. I suggested that the ethical response does not necessarily relate to any normativity of our action but has a much deeper meaning: productive passivity, or in Levinas's terms, non-intentional consciousness, turns out to be a mode of listening and being attentive. Only these existential forms are able, first, to shift, to displace and to unbalance the imaginary identity of the subject and, second, to recreate a new form of ethical becoming as being-for. The above analysis brought us to the conclusion that listening appears only because of a temporal dephasing that is diachronical time provoking a discontinuity inside temporalizing subjectivity. In listening, subjectivity is torn apart, broken and also shifted from its fixed cognitive position because the source of time does not belong to the subject but it is at the disposal of the other. The dephasing fractures the identity of the self and gives rise to a «ethical listening» and «being attentive» coming out from the subjectivity injected with the address of the other and structured as being for-the-other.

The paradoxical side of my conclusion is that even if the source of time originates from the other it is still found within subjectivity: it is an end of my time but it is a beginning of the time of the other in me when, in all my attentiveness, despite the past being gone, and neglecting my living present in being oriented towards the future, I am listening to the other and welcoming him/her. 
The task of reading or listening in the intersubjective relation is not an easy one. In its essence the traumatic experience of listening is ultimately frustrating and is pushed to the point of collapse due to temporal modes brought about by the other. However, it adumbrates a discovery of the subject who is constantly seeking for the origin of the self as temporalizing attentiveness towards the other.

\section{REFERENCES}

Bernet, R. (2002). Levinas's Critique of Husserl. In S. Critchley, R. Bernasconi (Eds.), The Cambridge Companion to Levinas. Cambridge: Cambridge University Press.

Depraz, N. (1994). Temporalité et affection dans les manuscripts tardifs sur la temporalité (19291935) de Husserl. ALTER: Revue de phenomenologie, (2), 63-86.

Duncan, R. (2000). Living Levinas: Non-intetnional Consciousness in Levinas and Karol Wojtyla. In Phenomenological Inquiry, Levinas in a Humanistic Context: a Tribute to a Thinker and Friend (189-204). Belmont: The World Institute for Advanced Phenomenological Research and Learning.

Duncan, R. (2006). Emmanuel Levinas: Non-intentional Consciousness and the Status of Representational Thinking. Analecta Husserliana, (90), 271-282.

Glendinning, S. (2007). In the name of phenomenology. London-New York: Routledge.

Henry, M. (2000). Incarnation, Une philosophie de la chair. Paris: Seuil.

Henry, M. (2008). Material Phenomenology. New York: Fordham University Press.

Husserl, E. (1966). Cartesian Meditation. The Hague: Martinus Nijhoff Publishers.

Husserl, E. (1991). On the Phenomenology of the Consciousness of Internal Time. Dordrecht: Kluwer Academic Publisher.

Levinas, E. (1974). En découvrant l'existence avec Husserl et Heidegger. Paris: Vrin.

Levinas, E. (1978). Existence and Existents. Netherlands: Kluwer Academic Publishers.

Levinas, E. (1985a). Ethics and Infinity. Pittsburgh: Dusquesne University Press.

Levinas, E. (1985b). Time and the Other. Pittsburgh: Duquesne University Press.

Levinas, E. (1998a). Discovering Existence with Husserl. Evanston: Northwestern University Press.

Levinas, E. (1998b). Entre nous: On Thinking-of-the-Other. New York: Columbia University Press. 
Levinas, E. (2000). Alterity and Transcendence. New York: Columbia University Press.

Levinas, E. (2004). Totality and Infinity. Pittsburgh: Duquesne University Press.

Levinas, E. (2001). Is it Righteous to be? Interviews with Emmanuel Levinas. Stanford: Stanford University Press.

Levinas, E. (2006). Otherwise than Being or Beyond the Essence. Pittsburgh: Duquesne University Press.

Montavont, A. (1994). Le phénomène de l'affection dans les analysen zur passiven synthesis. ALTER: Revue de phenomenologie , (2), 119-139.

Murawska, M. (2012). La transcendence et l'immanence. In Recherches Levinassienes (369-388). Louvain - Paris: Peeters.

Rodemeyer, L. (2006). Intersubjective Temporality. It's about Time. Dordrecht: Springer.

Welton, D. (2000). The Other Husserl. The Horizon of Transcendental Phenomenology. Bloomington : Indiana University Press. 